\title{
POVERTY IN THE BOOK OF PROVERBS: LOOKING FROM ABOVE?
}

Eben Scheffler

Biblical and Ancient Studies

University of South Africa

Only in heaven will we see how much we owe to the poor

for helping us to love God better because of them.

- Mother Teresa

\begin{abstract}
Employing the thoughts of French philosopher Henri Bergson (1859-1941), the question is asked if the wisdom perspective(s) in the Old Testament regarding poverty were essentially made from a stance of basic self-interest, which (despite some positive admonitions to help the poor) fails to really engage in the latter's plight. To locate the wisdom perspective(s) on poverty as one among many in the Bible, attention is briefly given to the latter. Various and diverse wisdom perspectives are also indicated especially in the book of Proverbs (reflecting Bergson's basic view). However, it is argued that the book also contains some proverbs which can be interpreted as going beyond a stance of pure self-interest. Some conclusions are drawn in view of present-day poverty eradication.
\end{abstract}

Key Words: Wisdom Literature, Proverbs, Philosophy, Poverty

\section{Introduction}

The interest for my argument below was inspired by the remarks made by Ronald Bailey (2010) concerning the Old Testament wisdom stance towards poverty, namely that it does not benefit the poor at all. The Old Testament sage argued from the viewpoint of the rich or middle class, because the wisdom teachers from ancient Israel per definition belonged to that class. In ancient Israel's wisdom literature, especially as reflected in the book of Proverbs, the poor mainly are depicted of being responsible for their own poverty. Not to discard Israelite tradition that depicts Yahweh as the god of the marginalised (e.g. Dt 15:4,7,11; Is 57:15; cf. Blomberg 1999:33-56) some positive admonitions to help the poor are not absent, but they are regarded by Bailey as to a great extend lip service to the plight of the poor, mere hand-outs (embalming of the wounds), actually keeping the poor alive in their continuing situation of poverty. The wisdom teachers of the Old Testament are therefore elitist, their wisdom pertains to the upper class, dealing with matters that concern them, their problems, how they should act (e.g. in business, political power, and sexual matters) and also how their behaviour towards poverty and the poor should or could be. Everything is said from their viewpoint and benefits themselves. The positive remarks to help the poor are not really genuine but only serve to keep the class distinctions intact (Pr 22:2: 29:13), so that they as wisdom teachers can remain in their privileged position. 
Baileys position reminds one of the Marxist analysis which Mosala made in his doctoral dissertation regarding to the social prophetic critique of the prophet Micah and the concern for the poor in Luke-Acts (1989:101-189; cf. also 1991). Mosala's main argument being on the one hand that the authors of biblical books could write, and by the sole virtue of this ability, were by definition elitist, and secondly that it is impossible for a middle class person to perceive the plight of the poor as they themselves do, and definitely not if the extreme poor are not solidarised with in their concrete situation and not directly spoken or listened to. Any literary, philosophical or theological contemplation on the matter, or even reflection or debate in a context of prosperity can only produce false results. Traditional biblical scholarships (even new sociological approaches and many black theologies) are still rooted in 'bourgeois' (white) society with its ideological assumptions (1989:190-191). According to him

... the Bible is the product, the record, the site, and the weapon of class, cultural, gender, and racial struggles... a biblical hermeneutics of liberation that does not take this fact seriously can only falter in its project to emancipate the poor and the exploited of the world. Once more, the simple truth rings out that the poor and exploited must liberate the Bible so that the Bible may liberate them (1989:193).

One can of course react immediately by indicating that Bailey and Mosala, although black theologians, are also situated in the middle class and in terms of their own argument their very argument is automatically refuted - except if they are the unexpected and extraordinary exceptions to the rule.

In what follows I choose to take their arguments seriously because of the implications they have for the interpretation of the Book of Proverbs. The latter is, as we all know, a very popular biblical book, and often published together with only the New Testament. The question is: if a reader of the Gospels identifies with Jesus' of Nazareth's uncontended stance and concern for the poor - as indicated by all worthy Historical Jesus scholars ${ }^{1}-$ will such a reader be contaminated by his reading of the Book of Proverbs and ponder 'philosophically' about the poor and their situation, regarding the latters' calamity as due to their own laziness, retardation and failures, and therefore lose all inspiration to help them concretely and take up their cause? If that is the case, the Book of Proverbs should be exposed for what it is and the reader should at least be compelled to make a choice regarding his or her own stance towards it. Or to put it in another way, if one identifies with the plight of the poor, which I personally think is the sane and wise thing in South Africa and the world at large to do, is the student of Old Testament wisdom literature to be warned against the book's conservative restorative ideology, or is the stance of wisdom literature to be recommended, embraced and even advocated as a meaningful instrument to eradicate the poverty of extremely poor people?

Before embarking on this question by looking at the text of proverbs, I refer firstly, for meaningful relief and perhaps more insightful understanding, to general western philosophy.

\section{On Bergson and Knowledge in the Context of the Perceiver}

Definitely Mosala, and Bailey (in all probability) were influenced by Marxism, but the idea that one cannot but perceive the world but from one's own stance was argued especially by

E.g. Renan [1863] 1991:104-111; Bornkamm [1956] 1975:67-73; Stauffer 1959:86-94; Jeremias 1971:110123; Schrottoff \& Stegemann 1978; Crossan 1991:72-88; 1994:60-62; Dunn 2003: 516-526; Borg 2006:185190 and Stegemann 2010:251-257,346-349,429-432 - to mention but a few. 
the French philosopher Henri Bergson (1859-1941). According to Bergson human beings are primarily to be explained in terms of the evolutionary process. Although Bergson typified the latter as a creative process (élan vital), our perception mechanisms as provided by the evolutionary process provides us not with objective pictures of our surroundings but messages that cause us to behave in certain ways in view of our own survival. Our (see discussion in Magee 1998:214; Russell 1946:760-761; Goudge 1967:289-290) ${ }^{2}$ conception of our surroundings is not what a series of detailed pictures taken by a camera would be like: it is highly selective, pragmatic and self-serving. Attention is paid only to what matters to us, the concept of our surroundings being built up in terms of our own interest and our overriding concern being our own safety and security. As biblical scholars we all know that the readers' contexts play a prominent part in the interpretation of texts, but Bergson emphasises that this is unavoidable and part of our biological make up. Our behaviour is self-centred in principle (to use a stigmatised term like 'selfish' in this context is therefore inappropriate) and the Christian or any altruistic challenge to step out of our context and to identify, side or empathise with the poor is an uncalled for and unnatural challenge. This may provide those who want to, but struggle to act on behalf of the poor with some unexpected consolation, but the haunting question still remains, is the world exposed to an inevitable negative apocalyptic fate or can the negative course on which it is be reversed through benevolent and compassionate human action? To put it in terms of the early Jesus movement: is the coming of God's kingdom (defined by Jesus as the alleviation of suffering) a pipedream?

If one glances at the philosophy of history, especially that of the western world, ${ }^{3}$ Bergson's observations seems to be confirmed, especially as far as the issue of poverty is concerned. The plight of the poor hardly functions in the thought of the great philosophers in terms of an endeavour to take the plight of the poor seriously. Karl Marx can be mentioned as an exception, but in view of the failure of communism, it is not too beneficial to have him on your side. A quick glance at the indexes of three 'histories of philosophy' seems to confirm this observation: In Russell's History of western philosophy (1962) there are nine references to poverty (pages 46, 197, 374, 438, 440, 441, 451, 459, 725) but all refer to the poverty ideal in an ascetic sense, reference being made to Thales, Aristotle, Peter Waldo, Francis of Assisi, William Occam, and Schopenhauer. In Störig's Weltgeschichte (1990) there are no references for the term 'Armut' and in Magee's The story of philosophy (1998) the British government's 'Poor Laws' of 1601 are referred to in view of their abolition (by emphasising 'individual responsibility'). Furthermore the liberal theories for a better society formulated by Jeremy Bentham (1748-1832) are mentioned (Magee 1998:182-184). Before Marx the latter is a relatively unknown and lonely voice indeed which only serves to confirm the unavoidable general perception that since philosophers are learned people and therefore elitist, they would not make the plight of the poor the object of their thinking, and if they do, then only in a limited and in all probability unproductive way, thereby corroborating Bergson's thesis. If one take a specific philosopher for example and his reception, the absence of reflection on poverty is also conspicuous. Guyer's 1992 book [21st printing in 2009] with 14 essays on Kant, has no reference to poverty, not even the

2 Russell, discussing Bergson's book Matière et mémoire (Matter and memory [1896] 1911) [1896] 1911), remarks: "But for the brain, one gathers, everything would be perceived, but in fact we only perceive what interests us. 'The body, always turned towards action, has for its essential function to limit, with a view to action, the life of the spirit.' It is, in fact, an instrument of choice." (1962:761).

As a Euro-South African I deliberately refrain in this article from engaging African proverbs or an 'African' appropriation of Old Testament proverbs, without ruling out the probability that I will do so in future (see the important work in this regard of Masenya 2006 and Kimilike 2006a, 2006b and 2006c). 
mentioning the absence of poverty or poverty eradication in Kant's thinking. In the Encyclopedia of Philosophy (8 volumes edited by Edwards 1967) there is no article on poverty nor on charity. Not so with the RGG ( $3^{\text {rd }}$ ed., cf. Surkau 1957:616-619; Kutsch 1957:622-624), indicating that poverty is more likely to receive attention in religion than in philosophy.

Bergson's thesis also seems to be confirmed when one investigates the occurrence of the concept in popular languages. Prinsloo's book on Afrikaans proverbs $(2004: 15,164)$ contains only a few references, all from the perspective of and in the interest of haves: ${ }^{4}$

- Die armes het julle altyd by julle (from the Bible, cf. Dt 15, Mk Mt).

- Armoede is geen skande nie.

- As armoede by the voordeur inkom gaan liefde by die agterdeur uit.

- Nood leer bid.

- As die nood op sy hoogste is, is die uitkoms op sy naaste.

- In die nood leer jy jou vriende ken.

- Nood breek wet.

Fergusson's (1983:189-193) Dictionary of proverbs contains no less than 119 proverbs under the rubric 'poverty' with various categories (its causes, its advantages, its disadvantages, its dangers, its relative unimportance, it relation to wealth, contempt for the poor and qualities of the poor). It furthermore contains 42 proverbs on giving to the poor (its value, the need for caution, the need for promptness, generous people, false generosity, small gifts, receiving gifts - Fergusson 1983:101-42). On the subject of wealth (in isolation) the dictionary has 128 entries (1983:248-252). Constraints of space forbid listing them all here. However, it is important to note that all these proverbs are also from an 'elitist' perspective, as the following selection (apart from those already mentioned with the Afrikaans ones) illustrates:

- Who spends before he thrives, will beg before he thinks (cause).

- Wealth is best known by want (effect).

- Where nothing is, a little does ease (advantage).

- It is easier to commend poverty than to endure it (disadvantage).

- When we have gold we are in fear; when we have none we are in danger (danger).

- Want of wit is worse than want of gear (relative unimportance).

- Content lodges oftener in cottages than palaces (poverty and wealth).

- There is one law for the poor and another for the rich (contempt).

- Under a ragged coat lies wisdom (quality).

Even English proverbs on giving to the poor are clearly made from a standpoint 'from above'. Consider the following examples (Fergusson 1983:101-103):

4 The English equivalents (or translation) of the Arikaans proverbs are as follows: (1) The poor are always with us, (2) Poverty is no disgrace, (3) When poverty comes in at the door, loves flies out of the window, (4) Necessity is the mother of invention, (5) The darkest hour is just before dawn; When the need is highest, the help is nighest, (6) A friend in need is a friend indeed, (7) Necessity knows no law. 
- What we spent we had; what we gave we have; what we left we lost (value).

- Be just before you are generous (caution).

- He gives twice who gives quickly (promptness).

- Small gifts make friends, great ones make enemies (small gifts).

- Who receives a gift, sells his liberty (receiving gifts).

- Nothing freer than a gift (direct contradiction to previous one).

This brief overview of Afrikaans and English proverbs regarding poverty serves only to corroborate the argument that even in popular wisdom thinking in the western world poverty is looked at from above, from a distance, and that Bailey and Mosalas' observations seems to be corroborated in the light of Bergson's philosophy. Or are they? In order to facilitate my own closer look at the Old Testament wisdom literature (with the focus on Proverbs), for the sake of relief the diversity of views on poverty which we encounter in the Bible as a whole is now briefly noted (for a more elaborate discussion see Levin 2001; Scheffler 211:115-135; Scheffler \& Van Heerden (eds) 2012; Blomberg 1999).

\section{Various Views on Poverty in the Old Testament}

As is the case regarding most human problems, there exists a kaleidoscopic diversity of views on poverty in the Old Testament. A quick glance at the various corpuses of literature provides a preliminary insight into this diversity, putting the Book of Proverbs into a particular relief.

- In the Pentateuch several laws, as they find expression in the Covenant (Ex 21:1-11; $22: 21-24 ; 22: 25 ; 22: 25-27 ; 23: 2,6 ; 23: 1$ ), Holiness- (Lev 19:10; 19:13,15; 25) and Deuterenomic Codes (especially Deut 15:1-18), prescribe how the poor should be positively treated, and how poverty should be prevented and combatted (Berges 2000:227-250).

- The Deuteronomistic history contains the catching story of Naboth's vineyard (1 Ki 21:1-9), where the exploiting king is prophetically criticised and challenged (see Bosman et al 1991; Farisane 2012:61-72).

- The Chronicler presents a positive view on the involvement of governing powers: Nehemiah 5 reports Nehemiah's exemplary behaviour sacrificing his own rights in order to address the poverty situation in the country (cf. Usue 2010).

- A diversity of views is also to be found in about 50 of the 150 psalms, of which the so-called 'piety of the poor' (Armenfrömmigkeit, cf. Rahlfs 1892; Scheffler 2011) is but one. In the psalms the king should care for the poor (e.g. Ps 72), God cares for the poor (Ps 9), God and the gods care for the poor (Ps 82), a descendant of David will care for the poor (Ps 32), God crushes the poor (Ps 88) and ordinary people should care for the poor (Ps 41 - cf. Lohfink 1992-1994).

- In the prophetic literature (especially Amos and Micah, also Isaiah and Jeremiah) the rich as well as the political and religious leaders are heavily criticised for exploiting the poor (Van Heerden 1991; Levin 2001:257-260; Blomberg 1999:57-86). ${ }^{5}$ 
From the above it emerges that the problem of poverty (which is never idealised in the Old Testament in an ascetic sense) seems to be considered from various angles in terms of its origins and in view of its prevention and eradication.

\section{Various Views on Poverty in Ancient Israelite Wisdom Literature}

Against this larger background reflecting the diverse attitudes to poverty eradication in the Old Testament, one can say in a nutshell that ancient Israelite wisdom literature continues the diversity. Moreover, due to its 'upper-class' situation in society it also manifests a unique stance.

Whereas the book of Proverbs (as well as Jesus Sirach and Wisdom of Solomon) generally advocates a charitable attitude towards the poor, ${ }^{6}$ the poor on the other hand are also reprimanded for being responsible for their own situation by being lazy or idle (emphasised by Le Roux 1996:66-67). Different from the conventional wisdom of the book of Proverbs, the critical wisdom of Job and Qohelet wrestles with the poverty in terms of the theodice problem (Berges 2004:19-23; Spangenberg 1991:240-245).

In his well-written overview on poverty in ancient Israelite wisdom literature, Berges (2004) advocates to my mind a 'canonical' approach to proverbs by attempting to construct a unitary positive view of the various proverbs on poverty in the book. However, if one studies the various proverbs regarding the poor it appears that even the Book of Proverbs reflects divers views regarding poverty. This can be expected since every single proverb in all probability had an independent existence and need not be interpreted in terms of one another. On the same issue there can even be proverbs reflecting diametrically opposite viewpoints. Regarding poverty (which in ancient Israel is generally regarded as negative and not to be desired in an ascetic fashion) the question can indeed be asked if a unitary wisdom perspective on poverty that is the function of the elite's social position is at all possible. This cannot be explored before attention is first paid to the various proverbs on poverty and the various or different perspectives they reflect. According to Kutsch (1957) ancient Israelite wisdom (as that of the ANE and especially Egypt) reflects the experiences of the poor, but on the whole also reflects a more profound understanding.

\section{Various Views on Poverty in the Book of Proverbs}

To facilitate the subsequent remarks on the Book of Proverbs, the following inventory of proverbs dealing with wealth and poverty is provided. Being done across the generally distinguished nine collections of the book, it illustrates the wide incidence of proverbs amongst various sages in ancient Israel. The inventory is also not limited to the poor in an exclusive sense. Wealth as the opposite pole is also included, because of the peculiar relationship between poverty and wealth, as can be clearly observed in the many proverbs that contain both concepts (Poverty and wealth are twin sisters! - Fergusson 1983:192; cf. $\operatorname{Pr} 22: 2 ; 29: 13)$.

against the poor (cf. Js 1:9-10,27; 2:3,16). The synoptic Gospels convey Jesus' attitude, but also lay particular emphases. In Mark's Gospel the command to the disciples to care for the poor ("Give you them something to eat") is pivotal (Mk 6:37), for Matthew caring for the poor implies caring for Christ (25:25-46) and Luke's Gospel is well-known for extensively elaborating on the theme (cf. Lk 1:53; 4:18-19; 6:20-21: 7:22; 11:39; 12:33; 14:13,21; 16: 18:22; $21: 3$ - see Scheffler 2011).

6 Whereas Proverbs speak about caring for the poor as 'lending to Yahweh', Wisdom of Solomon promises a reward in the afterlife. 


\section{Poverty in Proverbs: An Inventory}

\section{1-9 Prologue}

3:13-15 wisdom better than riches; 3:27-28 admonition to give; 3:33-35 God blesses the virtuous and punishes the wicked; 6:6-11 ant parable: idleness causes poverty

\section{0-22:16 The Major Solomonic Collection}

\section{0-15:33 Opposition between the wise and the fool}

10:2 against dishonest profit; 10:3 God cares for the virtuous and thwarts the greedy; 10:4-5 idleness causes poverty; 10:15 wealth is good and poverty bad; 10:21 the virtuous become rich and the fools poor; 10:22 God the cause of wealth, not toil; 11:1 against false balances; 11:4 wealth is no security; 11:16 idleness causes poverty and enterprise wealth; 11:18 illusory versus solid wealth; 11:24 the extravagant grows rich, the mean poor; 11:26 blessing for the seller of wheat; 11:28 against trust in riches ;11:29 fool as slave of the wise; 12:11 who works have bread; 12:27 idleness causes poverty, pro diligence; 13:7 rich and poor pretending; 13:8 wealth may save one's life; 13:11 pro gradual wealth accumulation; 13:18 lack of discipline causes poverty; 13:21 sin causes misfortune, virtue good fortune; 13:22 the good man's children inherit, he obtains the sinners wealth; 13:23 the poor that works has food, lack of justice causes death; 13:25 the virtuous can indulge, the wicked goes hungry; 14:4 oxen cause wealth; 14:20 their neighbours rejects the poor, the rich have friends; 14:23 work causes wealth, idleness poverty; 14:31 against oppressing the poor, pro being kind to them; 14:34 the king favours the wise servant; 15:6 treasure for the virtuous, anxiety for the wicked; $14: 16$ better with God and poverty than wealth with anxiety; 15:19 idleness causes difficulty, work prosperity; 15:25 Yahweh impoverish the proud and protect the widows; 16:8 better little with virtue than unjust wealth

\section{6-22:16 Training for Kings and Judges}

16:16 wisdom better than riches; $16: 19$ better humble and poor than proud and rich; 16:26 hunger drives to work; 17:1 better little and peace than feasting with conflict; 17:2 a wise slave can inherit; 17:5 against mocking the poor; 17:17 a brother helps in need; 17:19 brothers and friends help one another; 18:20-21 one's words feed him; 18:23 the poor pleads, the rich answers harshly; 19:1 better poor and honest; 19:4 wealth draws many friends, poverty loses them; 19:6-7 the giver draws friends, the poor loses brothers and friends; 19:10 against fools living in luxury and slaves ruling; 19:13 a foolish son can ruin his father; 19:14 wealth can be inherited, not a good wife; 19:15 idleness causes poverty; 19:17 the benefactor lends to Yahweh; 19:22 better poor and kind than lying; 19:23 the fear of Yahweh causes prosperity; 19:24 the idler cannot feed himself; 20:4 idleness causes poverty; 20:10 against false measures; 20:13 too much sleep causes poverty; 20:21 against quick property; 21:5 patient labour causes wealth, haste poverty; 21:13 not helping the poor will be punished; $21: 17$ pleasure seeking causes poverty; $21: 19$ better poor than a scolding woman; 21:25-26 the idle covets and gets nothing, the virtuous gives continually; 22:1 a good reputation better than wealth; 22:2 Yahweh made the rich and the poor; 22:4 humility and fear of Yahweh causes prosperity; 22:7 the rich rules the poor; 20:9 the sharer with the poor will be blessed; 22:13 against idleness; 22:16 oppressing the poor while giving to the rich causes one's poverty 


\section{2:17-24:22 A Collection of the Sages (Amenemope)}

22:22-23 against oppressing the poor, God will revenge; 22:26-27 surety leads to poverty; 22:29 the industrious will serve kings; 23:4-5 against chasing wealth, it can disappear; 23:10 against displacing landmarks to disadvantage orphans; 23:20-21 overindulgence causes poverty; 24:3-4 wisdom causes wealth; 24:15-16 the virtuous will survive, the wicked not; 24:19-20 don't envy the wicked who will perish; 24:21-22 respect the king and Yahweh to avoid ruin

\section{4:23-34 A Second Collection of the Sages}

24:27 first food then home; 24:34 idleness causes poverty

\section{5-29 A Second Solomonic Collection (By Hezekiah)}

25:25-22 giving to the enemy; 26:13-15 idleness causes poverty; 27:7 hunger give good taste; 27:13 against surety; 27:18 care for trees provides food; 27:23-27 care for animals provides prosperity; 28:3 oppressing the poor causes hunger; 28:6 better poor and honest; 28:8 against usury and interest; $28: 11$ a poor man can be wiser than the rich; 28:15 against bad rulers of the poor; 28:19 work provides food, idleness poverty; 28:20 trustworthiness blessed, against quick wealth; 28:22 greediness leads to wealth; 28:27 giving to the poor rewarded, not giving punished; 29:3 harlotry causes poverty; 29:4 just king causes prosperity, a bribed one ruin; 29:7 the virtuous engages for the rights of the poor, the wicked not; 29:13 Yahweh provides for rich and usurer; 29:14 a king pro the poor rewarded; 29:21 pampering a servant makes him ungrateful

\section{0:1-14 The Agur Sayings}

30:7-9 midway between wealth and poverty; 30:14 the wicked devours the poor

\section{0:15-33 Numerical Proverbs}

30:22 against a slave ruling and a fool fed

\section{1:1-9 The Sayings of Lemuel's Mother}

31:6-7 let the poor drink to forget their suffering; 31: 8-9 the king should speak for the poor, upholding their rights

\section{1:10-31 The Woman of Worth}

31:10-19 a good wife produces wealth; 31:20 the woman of worth caring for the poor; $31: 21$ the woman of worth cares for her family and servants

Out of the approximately 600 proverbs in the book of proverbs to my mind about 120 deals with poverty and riches (Whybray 1990:15 distinguished exactly 156 only in the two socalled Solomonic collections of 10-22 and 25-29). One could attempt to discuss and explain their diversity in content by studying and relating the proverbs in the context of the different sources of the book (the prologue, the Solomonic collections, the wisdom of Ameneope, the small 10 proverb collection of 24:24-34, the sayings of Agur [30:1-14], the numerical sayings of 13:50-33 [in which the theme of poverty is virtually absent], the teaching of Lemuel's mother, and the acrostic poem on the worthy [note not poor!] woman with which the book concludes (31:10-31; Masenya 2004). It is interesting to note that both Von Rad (1970:28) and Kaiser (1984), in discussing the various sources or collections, 
nowhere give attention to the theme of poverty and wealth in Proverbs. May this in itself be due to 'elitist' scholarship, or their being situated in a country (Germany) where poverty is not such a burning issue?

A second approach would be to discuss the various proverbs diachronically as was to my mind done well by Spangenberg (1991). However, as Spangenberg himself indicated (1991:230), diversity appeared in the different distinguished periods themselves. Moreover, such a chronological distinction camouflage to a large extent the long life which proverbs could have, thus minimising their intrinsic diversity. If Qohelet for instance quotes and disagrees with a proverb of so-called 'traditional' wisdom (Spangenberg 1991:243), it implies that the 'old proverb' is still alive. His debate actually emphasises the diversity between the Proverbs and among wisdom teachers. ${ }^{7}$

In view of my present purpose of taking up Bailey and Mosalas' challenges in terms of Bergson's said views on human perception, I will in what follows make the diversity itself my focus and quote and briefly discuss 12 proverbs that express to my mind the different perspectives the best.

The following diverse (sometimes contradicting, sometimes complementary) perspectives on poverty can to my mind be distinguished. These pertain to the (1) characteristics, (2) causes of and (3) measures to combat poverty.

\section{- The Characteristics of Poverty}

1 Poverty is viewed as negative and an evil. Proverbs 10:15 reads:

$$
\begin{aligned}
& \text { The wealth of the rich is their fortress; } \\
& \text { רישֶׁ,ם: the poverty of the poor is their ruin (NRSV). }
\end{aligned}
$$

In the Old Testament at large (and especially in the book of Proverbs) ${ }^{8}$ there is no positive evaluation made of poverty, it seems to be communis opinio that it is to be avoided. Poverty leads to destruction. ${ }^{9}$ The Agur-saying (30:9) concurs: Being the 'mother of crime', ${ }^{10}$ poverty can lead to stealing and profaning the name of God. Although wealth is generally accepted as advantageous as in 10:15 (repeated verbatim in 18:11), the Agur-saying contradicts this view since wealth can lead to defying Yahweh (30:8). For him soberness

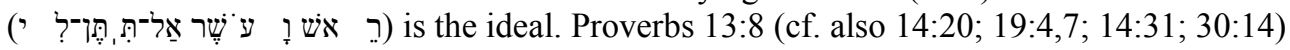
corroborates 10:15, whereas $11: 4 ; 23: 5$ and 28:6,11, without condoning poverty, communicates a relatively different view (Toy 1977:208).

Cf. also the remark by Kaiser (1984:377): "Bei den Sammlungen kann Material unterschiedlicher Genese zusammengeordet word sein... Die Sozialstruktur ist im ganzen alttestamentliche Zeitraum unbeschadet der tiefgreifende politischen Einschnitte relativ stabil geblieben."

8 It can be argued that in the book of Job that poverty serves the 'positive' function to 'test' Job's faith. If, however, the book is interpreted as a comprehensive narrative to deal with the theodice problem, poverty remains evil, with the (unanswered) question being why God let the just suffer.

9 Noteworthy is the (mis)interpretation of the LXX: $\sigma v v \tau \rho \mathrm{s} \quad \delta \sigma \varepsilon \beta \quad v \pi \varepsilon v \quad \alpha$ (poverty is the ruin of the ungodly), thereby blaming the poor for their own poverty (unfortunately not discussed by Cook 1997).

10 Note also two other English proverbs: The devil dances in an empty pocket and There is no virtue that poverty destroys not (Fergusson 1983:191), although in 10:15 no ethical behaviour is per se implied. 
2 The poor and the rich are both made by God. In Proverb 22:2 it is stated:

$$
\begin{aligned}
& \text { Therich and poor meet together: } \\
& \text { the LORD is the maker of them all (KJV). }
\end{aligned}
$$

Another version of this Proverb (emphasising class distinction) occurs in 29:13, where the rich is replaced by 'oppressor' and Yahweh as maker as the one 'giving light' to both. The saying recognises social classes, but the negativity which this implies is limited by an appeal to creation theology. This saying obviously reflects the elitist stance of the author, since it can hardly be expected that the poor themselves would be satisfied with such an order. Or, if the proverb is read from a perspective 'from below', does it imply that rich and poor are equal before God (being the maker of both) and that the classes should be abolished? (cf. Davis 2000:96; Plöger 1984:253,346). To my mind, in view of the rest of the book, and in the context of ancient Israel, the former applies (cf. Toy 1977:511; Mckane 569-570; 640; Spangenberg 1991:236).

\section{- The Causes of Poverty}

Various reasons for poverty are found in the book of Proverbs. At least seven causes can be distinguished. In six the poor cause their own poverty, whereas in one the cause is located outside themselves.

3 Firstly, the poor cause their own poverty by being idle and lazy. Consider 10:4:

$$
\begin{aligned}
& \text { A slack hand causes poverty, } \\
& \text { but the hand of the diligent makes rich (NRSV). }
\end{aligned}
$$

Starting with the famous ant-parable in the prologue (6:6-11), this motif is repeated and emphasised (cf. the artistic poem in 24:30-34) so often in the book (at least 15 times $^{11}$ ) that laziness is sometimes regarded as the main cause for poverty (e.g. Le Roux 1996). The danger of this view is that the poor who really were victims (e.g. because of robbery and exploitation as in 30:14) are accused falsely. It should also be kept in mind that the elitist authors did not merely look upon the poor with contempt, but warned and instructed their students to be diligent to secure their safety and security (to use Bergson's terms). Despite the view in one proverb that relativises toil in favour of Yahweh's blessing ( $\operatorname{Pr} 10: 22)$, they were of the firm opinion (based on experience) that hard work (together with humility and fear of Yahweh - cf. 22:4) produces prosperity. Idleness or victimisation as causes of poverty? Both can be right, depending on the context.

4 Secondly, the poor cause their own poverty by loving unbridled pleasure. Proverbs 21:17 states:

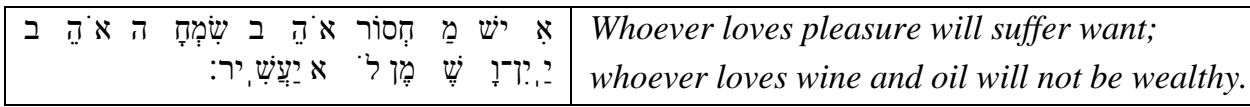

${ }_{11}$ Cf. Proverbs $6: 6-11 ; 10: 4-5 ; 11: 16 ; 12: 27 ; 14: 23 ; 15: 19 ; 19: 15,24 ; 20: 4 ; 20: 13 ; 21: 25-26 ; 22: 13 ; 24: 30-34$; $26: 13-15 ; 28: 19$. 
There may be a relation between love for pleasure and laziness, but not necessarily. Since Proverbs nowhere advocates asceticism (cf. 3:10: 21:20: 27:9), one can assume that overindulgence is implied (Toy 1977:405) which directly leads to impoverishment (as in 23:20-21), obviously due to the costs involved in terms of time and money. The same applies to harlotry $(29: 3){ }^{12}$ The insight is clearly from wealthy people who reflect on the dangers that can lead to impoverishment.

5 Thirdly, the poor cause their own poverty through a lack of discipline.

Consider Proverbs 13:18:

\begin{tabular}{|c|c|}
\hline 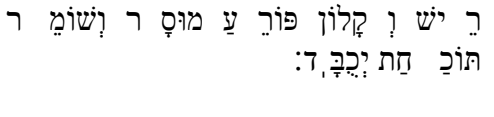 & $\begin{array}{l}\text { He who ignores discipline comes to poverty } \\
\text { and shame, but whoever heeds correction is } \\
\text { honoured (NIB). }\end{array}$ \\
\hline
\end{tabular}

Discipline and correction in the sense of instruction and admonition (criticism, advice) is central in the book of Proverbs (cf. $1: 25 ; 8: 33 ; 12: 1 ; 13: 13 ; 15: 5,32$ ), but only here the reversed correlation with poverty is mentioned (perhaps implied in 1:25-27). Again the statement is made from an upper class perspective (systematic education hardly took place amongst poor people) which links honour and shame (in the sense of status and contempt Plöger 1984:162; McKane 1970:456) to wealth and poverty.

6 Fourthly, the poor cause their own poverty by being foolish (without wisdom).

According to Proverbs 10:21

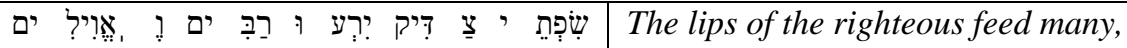

$$
\begin{aligned}
& \text { but fools die for lack of understanding. }
\end{aligned}
$$

Foolishness can be regarded as an umbrella term for all the causes already mentioned (lack of the virtues of diligence, sobriety and discipline). As such any other virtue which constitutes wisdom and righteousness is covered by this proverb. The righteous (who can control his speech and is like a good shepherd) is the one that gives, and is therefore a 'have' whose stance is here represented. To my mind McKane (1970:420; cf. also Ringgren 1980:48), although emphasising the general influence of the righteous beyond himself in the community, underplays the material implications of this proverb.

7 Fifthly, poverty is a curse or punishment for being wicked or unjust. Proverbs 13:25 states:

\begin{tabular}{|c|c|}
\hline 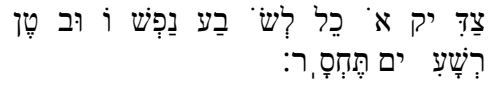 & $\begin{array}{l}\text { The righteous eat to their hearts' content, } \\
\text { but the belly of the wicked goes empty. }\end{array}$ \\
\hline
\end{tabular}

Wickedness leads to poverty (empty stomach) which can be interpreted as punishment, even though God (who created the order) is not explicitly mentioned as he is in 10:3

12 Cf. Jesus Sirach 18:33-19:1 which warns against indulgence which leads to an empty purse. In 21:17 'oil' most probably refers to fat foods (Plöger 1984:247). 
(thwarting the craving of the wicked). The correlation between righteousness and feasting (no asceticism or Armenfrömmigkeit!) clearly situates both proverbs amongst the elite.

8 Sixthly, according to Proverbs 22:26-27, standing surety can lead to one's own poverty

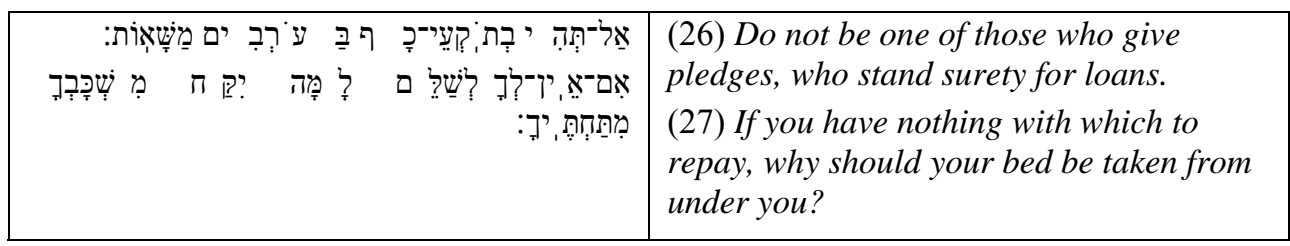

This Proverb is the third of the Amenemope collection, but general warnings against surety occur in also 6:1-5, 11:15 and 17:18. In Proverbs 20:16 (repeated in 27:13) the consequences in terms of forfeiting property are spelt out. Losing one's bed and clothes implies extreme poverty. These clearly are proverbs that circulated amongst the elite. The reflection is on avoiding poverty, not to take up the cause of the poor.

9 In the seventh place, the poor become victims because they are exploited and oppressed by the wicked. Consider Proverbs 30:11-14.

\begin{tabular}{|c|c|}
\hline 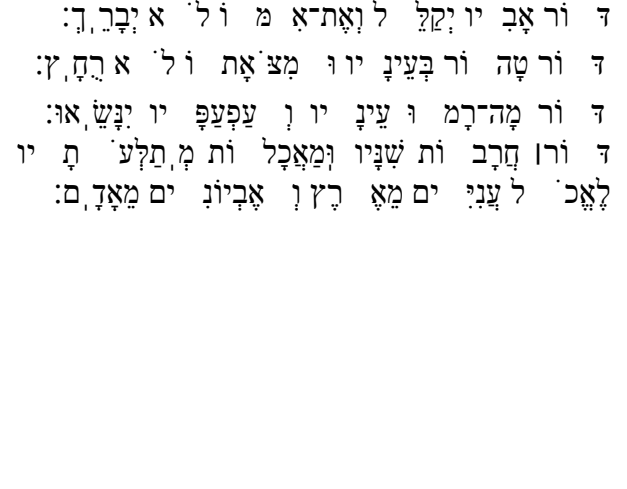 & $\begin{array}{l}\text { (11) There are those who curse their } \\
\text { fathers and do not bless their mothers. } \\
\text { (12)There are those who are pure in their } \\
\text { own eyes yet are not cleansed of their shit. } \\
\text { (13) There are those - how lofty are their } \\
\text { eyes, how high their eyelids lift! } \\
\text { (14) There are those whose teeth are } \\
\text { swords, } \\
\text { whose jaw teeth are knives, } \\
\text { to devour the poor from off the earth, } \\
\text { the needy from among mortals. }\end{array}$ \\
\hline
\end{tabular}

This multiple saying (which resembles the numerical sayings that follow) ${ }^{13}$ forms the climax of the Agur sayings and (together with the saying on sobriety [30:7-9] and the acknowledgment of the limitations of knowledge - cf. 30:2-4) defines him as a unique thinker (but not from the poorest of the poor). In 30:10 he also sides with the poor (= slave). This proverb is important since it does not by definition attributes poverty to the poor's own doing (cf. previous examples). The poor can also be poor while they are innocent victims. This view resembles that of the prophets (cf. Am 4; Mi 3) but although it can include, it is not aimed directly at the leaders of the people. However this perspective is not unique to Agur. In Proverbs 22:16 and 28:3 the poor are also victims of the wicked and in 28:15 the wicked is

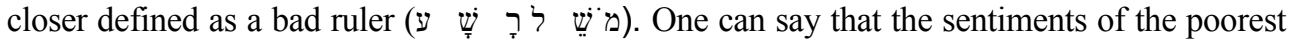
of the poor are heard in these a-typical 'prophetic' proverbs, but at the most they are uttered voices of the middle class on behalf of them. In Proverbs 22:22-23, the rich are also

13 Kaiser 1983:378, because of this resemblance, attributes chapter 30 as a whole to Agur. However, in the numerical sayings nothing there is only a negative reference to the poor (30:22-23). 
According to sayings 3-8 above, reflection on how to avoid poverty forms part and parcel of wisdom, and in the process various causes of poverty are revealed. In saying 9 the poor is considered as victims of wicked behaviour with the consequence that righteous people should take up their plight and alleviate their poverty. To four sayings reflecting this motif we now turn.

\section{- Measures to Eradicate Poverty}

10 The king should care for the poor. Proverbs 31:8-9 records the advice of King Lemuel's mother to him:

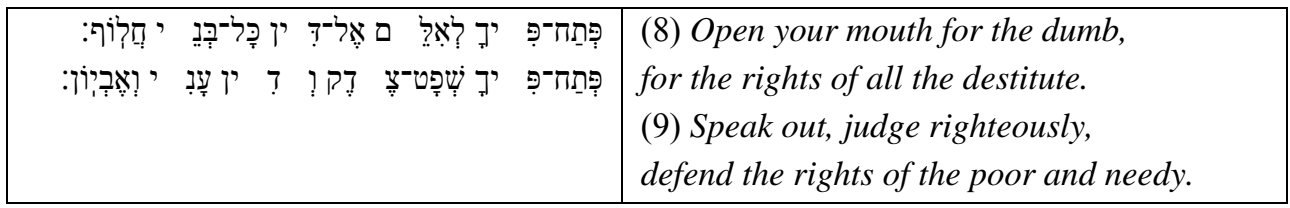

The saying reminds of the function of the king in Psalm 72 and Nehemiah's exemplary behaviour described in Nehemiah 5. In 29:14 a long rule is promised as a reward for a king that is kind to the poor. The king's function in Proverbs pertains mainly to the justice system, no reference being made to other poverty eradication measures. The Proverb is an admonition to the king by the queen mother (both part of the elite) on behalf of the poor.

11 People should care for the poor, motivated by fear. Proverbs 21:13 states

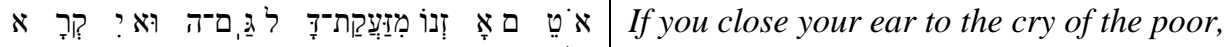

$$
\begin{aligned}
& \text { עou will cry out and not be heard. }
\end{aligned}
$$

Put in male language, the intention of the proverb is to motivate anybody (in view of 31:20 women can hardly be excluded) to care for the poor by listening to their cry. The person addressed is as of yet not crying, and therefore belongs to the elite. The proverb motivates through negative conditioning (as in 11:26a; 28:27b): not through compassion for the poor but out of the fear for the possibility that one will become poor oneself (the law of retaliation - cf. Toy 1977:403). ${ }^{14}$

12 People should care for the poor, motivated by a reward. Consider 19:17:

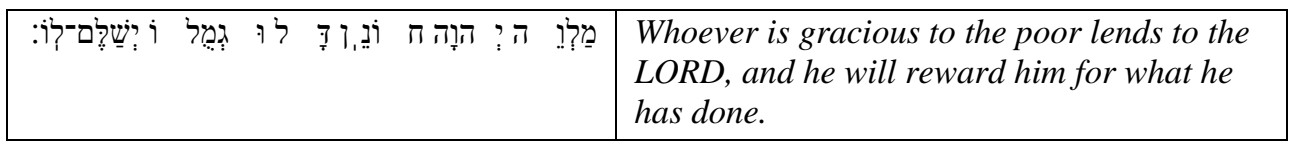

This proverb uses positive conditioning (not fear but the promise of compensation) to motivate care for the poor (cf. 14:21:22:9). As such the motivation is less suspicious, but the main motive is not unconditional compassion. The gracious one can only belong to the

14 Refering to the poor's 'imprecation to Yahweh', Jesu Sirach 4:1-6 also uses negative reinforcement. 
middle or upper class (cf. 11:26b; 28:6) since it is not the 'fellow-poor' that is talked about. $^{15}$

13 Unconditional care for the poor is praised and advocated. Consider the praise for the woman of worth in 31:20:

\begin{tabular}{|c|c|}
\hline 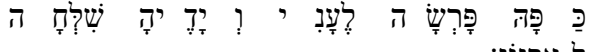 & $\begin{array}{l}\text { She opens the palm of her hand to the poor, } \\
\text { and sends out her hands to the needy. }\end{array}$ \\
\hline
\end{tabular}

The woman of worth not only looks well after her household (31:21), which would include the servants, but moreover (in crossing her borders) reaches out to the poor and needy in the community. The metaphors used (open hand palms and 'sent out' hands) creates a picture of somebody whose care is beyond mere involvement in charity work but unconditionally based on compassion. ${ }^{16}$

\section{Conclusion}

To my mind a responsible appropriation of the proverbs on poverty should take account of Bailey and Mosalas' remarks regarding its elitist origin, recognising that in most instances the critique can indeed be applied to most proverbs. These can indeed be explained in terms of Bergson's view on human perception. One can imagine these proverbs being formulated by their authors with their own safety and security in mind. As such most of the proverbs on poverty can therefore not be used as a contemporary appropriate guideline to help the poor, but rather as an instrument to advance the self-understanding of present-day theologians (or anybody who is not poor) who reflect on the poor. The proverbs are in this sense appropriated against their grain, and 'reveal' the 'elitist' biblical reader as looking from above on poverty. Such an appropriation indicates that one should not confuse pitying the poor, cherishing some positive thoughts about them and even certain actions to their benefit with in-depth empathy, compassion or concrete solidarity with them.

However, Bailey and Mosalas' views do not take sufficient account of the diversity amongst the proverbs on poverty. The question also remains whether it is at all possible to break out of the captivity of being elitist and cultivating a real concern for the poor that is not only intended or having the effect of maintaining the status quo. If one wants (as a Bible reader) to make a contribution to the eradication of poverty in our present world, the biblical tradition as a whole should be dialogued with, taking even account of extra-biblical thought (even pure economic thought as advocated by Sachs 2005). In Proverbs Lemuel's mother and the 'woman of worth' of chapter 31 leads the way. Both break borders. To my mind, in the contemporary world people like Mohatma Ghandi ([1929] 2007), Albert Schweitzer ([1931] 1948) and Mother Teresa of Calcutta ${ }^{17}$ made such a breakthrough.

\footnotetext{
15 In Wisdom of Solomon the reward is even extended to the afterlife (Berges 2004:25).

16 Masenya 2004:156, referring to the caring of the woman of worth and African people as "culturally caring and compassionate people", argues that positive elements regarding caring for the poor in African contexts should be revived in order to "contribute to the welfare of all South Africans in the post-apartheid South Africa" - sentiments with which I wholeheartedly agree.

17 In the South African context Beyers Naude can can be mentioned, and in African-South-African context Nelson Mandela who originated from a royal family (Mandela 1994:3). For Mandela's own profound sayings on poverty (e.g. "Where poverty exist, there is no true freedom"), see Mandela 2011:190-194.
} 
Allow me, without being too sentimental, to report about a recent visit to the church of the flagellation in Jerusalem. Three Mother Teresa sisters visited the church to pray for five minutes. Our guide explained that they do this regularly because of the stress they experience in the conflict areas of the Palestinian territory where they work. What is remarkable about the Mother Teresa sisters is that they are the only Christian group that is allowed by both Palestinians and Jews to work in these conflict areas. Incidentally, one was white, one Indian, and the third black.

I conclude with an adage (punning Descartes) which I want to, but consistently fail to live up to, but which one can only hope should become everyone's motto in life: Compatior, ergo sum. ${ }^{18}$

\section{BIBLIOGRAPHY}

Berges, U 2000. Armoede en haar bestreiding in die wette van die Ou Testament. Tijdschrift voor Theologie 40(3). 227-250.

Berges, U 2004. 'Kan er vrede zijn tussen een rijke en een arme?' (Sir 13, 18): Armoede en rijkdom in de wijsheidsliteratuur. Tijdschrift voor Theologie 44(2). 14-27.

Bergson, H [1896] 1911. Matter and memory. New York.

Blomberg, CL 1999. Neither poverty nor riches: A biblical theology of material possessions. Leicester: Apollos.

Bornkamm, G [1956] 1975. Jesus von Nazareth. 10. Aufl. Stuttgart: Kohlhammer.

Bailey, R 2010. Communication during the discussion of the module "The Bible and the eradication of poverty", (cf. Scheffler \& Van Heerden [eds.] 2012) being taught at the University of South Africa.

Borg, MJ 2006. Jesus: Uncovering the life, teachings, and relevance of a religious revolutionary. New York: HarperCollins.

Bosman, HL, Gous IGP \& Spangenberg, IJJ (eds.) 1991. Plutocrats and paupers: Wealth and poverty in the Old Testament. Pretoria: Van Schaik.

Cook, J 1997. The Septuagint of Ptoverbs - Jewish and/or Hellenistic Proverbs?: Concerning the Hellenistic colouring of LXX Proverbs. Leiden: Brill.

Crossan, JD 1991. The historical Jesus: The life of a Mediterranean Jewish peasant. Edinburgh: T\&T Clarke.

Crossan, 1993. Jesus: A revolutionary biography. New York: HarperSanFrancisco.

Dunn, JDG 2003. Jesus remembered. Grand Rapids: Eerdmans.

Edwards, P (ed.) 1967. The encyclopedia of philosophy. (8 vols.) New York: Macmillan.

Farisane, E 2012. The Naboth's vineyard story (1 Kings 21) and poverty eradication, Scheffler \& Van Heerden 2012:62-72.

Fergusson, R 1983. The penguin dictionary of proverbs. London: Bloomsbury Books.

Gandhi, MK [1929] 2007. An autobiography: Or the story of my experiments with truth. London: Penguin.

Guyer, P (ed.) 2009. The Cambridge companion to Kant. Cambridge: CUP.

18 "I have compassion (suffer with others), therefore I am." (quoted by Spangenberg 1991:242). 
Goudge, TA 1967. s v Bergson, Henri. The encyclopedia of philosophy, Edwards, P (ed.), 287-295. Vol 1. New York: Macmillan.

Guyer, P (ed.) 2009. The Cambridge companion to Kant. Cambridge: CUP.

Jeremias, J 1971. Neutestamentliche Theologie: Erster Teil: Die Verkündigung Jesu. Gütersloh: Gerd Mohn.

Joubert, S 2000. Paul as benefactor: Reciprocity, strategy and theological reflection in Paul's collection. Tübingen: Mohr Siebeck.

Kaiser, O 1984. Einleitung in das Alte Testament: Eine Einführung in ihre Ergebnisse und Probleme. Gütersloh: Gerd Mohn.

Kimilike, LP 2006a. An African perspective on poverty proverbs in the book of Proverbs: An analysis on transformational possibilities. Unpublished DTh thesis, University of South Africa, Pretoria.

Kimilike, LP 2006b. Using African proverbial folklore to understand the holistic poverty eradication framework in the book of Proverbs. OTE 19(2):405-417.

Kimilike, LP 2006c. 'The poor are not us': An exploration into the transforming possibilities of Old Testament and African proverbs on poverty. OTE 19(2):418-428.

Kutsch, E 1957. sv “Armut”, RGG 3.

Le Roux, JH 1996. Woorde van wysheid: Lewenskuns vir elke dag. Vereeniging: Christelike Uitgewersmaatskappy.

Levin, C 2001. The poor in the Old Testament: Some Observations. Religion \& Theology 8. 253-273.

Lohfink, N 1992-1994. Die Armen in die Psalmen. Teil I \& II. (Vorlesungsmanuskript Wintersemester). Frankfurt am Main: Hochschule Sankt Georgen.

Mandela, N 1994. Long walk to freedom. London: Abacus.

Mandela, N 2011. Nelson Mandela by himself. Johannesberg: Pan Macmillan.

Marland, S, Clements, A, Rae, L \& Valvasori, A 2008. World poverty for dummies. Milton: Wiley.

Magee, B 1998. The story of philosophy. London: Dorling Kindersley.

McKaine, W 1970. Proverbs: A new approach. London: SCM.

Masenya, M 2004. How worthy is the woman of worth? Rereading Proverbs 31:10-31 in African-South Africa. New York: Peter Lang.

Masenya, M 2006. Challenging poverty through Proverbs. OTE 19(2):393-404.

Mosala, I 1989. Biblical Hermeneutics and Black Theology in South Africa. Grand Rapids: Eerdmans.

Mosala, I 1991. Ownership or (non)ownership of land forms the basis of wealth and poverty: A Black Theological perspective, in Bosman et al 1991:20-24.

Plöger, O 1984. Sprüche Salomos (Proverbia). Neukirchen: Neukirchener Verlag.

Prinsloo, AF 2004. Spreekwoorde en waar hulle vandaan kom. Kaapstad: Pharos.

Rahlfs, A 1892. 'Ani und 'Anaw in den Psalmen. Gottingen: Dieterichse Verlagsbuchhandlung.

Renan, E [1863]1991. The life of Jesus. New York: Prometheus Books. 
Ringgren, H 1980. Sprüche in Ringgren, H \& Zimmerli, W, Sprüche/Prediger: Übersetzt und erklärt, 1-119. Aufl. Göttingen: Van den Hoeck.

Russell, B 1962. History of western philosophy and its connection with political and social circumstances from the earliest times to the present day. London: George Allan.

Sachs, JD 2005. The end of poverty: How we can make it happen in our lifetime. London: Penguin.

Scheffler, E 2011a. Luke's view on poverty in its ancient (Roman) economic context: A challenge for today. Scriptura 106:115-135.

Scheffler, 2011b. Pleading poverty (or identifying with the poor for selfish reasons): On the ideology of Psalm 109. OTE 24(1). 192-207.

Scheffler, EH \& Van Heerden SW (eds.) 2012. The Bible and the eradication of poverty: Tutorial Letter 501/OTS2604. Pretoria: Unisa.

Schrottoff, L \& Stegemann, W 1978. Jesus von Nazareth - Hoffnung der Armen. Stuttgart: Kohlhammer Verlag.

Schweitzer, A [1931] 1948. My life and thought: An autobiography. London George Allen.

Spangenberg, I 1991. "The poor will always be with you". Wealth and poverty in a wisdom perspective, in Bosman et al 1991:246.

Stegemann, W 2010. Jesus und seine Zeit. Stuttgart: Kohlhammer.

Störig, HJ 1990. Kleine Weltgeschichte der Philosophie. 15. Aufl. Stuttgart: Kohlhammer.

Surkau, HW 1957. sv “Armenflege”, RGG 3.

Stauffer, E 1959. Die Botschaft Jesu: Damals und heute. Bern: Francke Verlag.

Toy, CH 1977. A critical and exegetical commentary on the book of Proverbs. Edinburgh: T\&T Clarke.

Von Rad, G 1970. Weisheit in Israel. Neukirchen: Neukirchener Verlag.

Usue, EO 2010. Nehemiah's region-ethical wisdom in resolving an economic crisis in postexilic Judah (Neh 5:1-19): A lesson to be learned in Africa. Paper presented at the OTSSA's 53 ${ }^{\text {rd }}$ Annual Congress, 15-17 Sept 2010. North-West University's Vaal Triangle Campus.

Van Heerden, SW 1991. Prophets and profiteers: Prophetic perspectives on wealth and poverty, in Bosman et al 1991:228-146.

Whybray, RN 1990. Wealth and poverty in the book of Proverbs.

Sheffield: Sheffield Academic Press.

Von Rad, G 1990. Weisheit in Israel. Neukirchen: Neukirchener Verlag. 